EASTERN EUROPEAN JOURNAL OF TRANSNATIONAL RELATIONS

2020 Vol. 4 No. 2

DOI: 10.15290/eejtr.2020.04.02.05

Katarzyna Kamińska ${ }^{1}$

University of Silesia in Katowice, Poland

\title{
Joint Physical Custody After Parental Separation: A Polish Perspective
}

\begin{abstract}
The aim of this paper was to present the characteristics of joint physical custody in Polish family law. For this purpose the relevant regulations of the Polish law were analysed. In the paper, the substantive as well as the procedural provisions were compared. The Family Court may award joint physical custody if the parties have made an agreement, consistent with the welfare of the child, or in the absence of such a parenting agreement, having regard to a child's right to both parents. One hypothesis assumes that joint physical custody does not mean only symmetric child custody arrangements, and its proper application by courts is determined by taking into account many different factors. In the paper, the results of the examination referred to joint custody in child custody law in Germany and the Swedish experience of joint physical custody, were presented. The main advantage of joint physical custody is to provide both parents equal control over decision regarding a child's upbringing and to split the time that a child spends living with each of them. This paper contains a reflection on joint physical custody in the face of COVID-19. The current pandemic is having an enormous impact on families. During this particular time, it is time to become more cooperative and more fluid, not less.
\end{abstract}

Keywords: joint physical custody, shared parenting, COVID-19, coronavirus pandemic, child welfare.

\section{Introduction}

The institution of joint physical custody has not been regulated expressis verbis in Polish family law. However, current provisions do not preclude de lege lata such

$1 \quad \mathrm{PhD}$ candidate at the University of Silesia in Katowice, Faculty of Law. ORCID: 0000-00024438-0127. E-mail: katarzynakaminska@us.edu.pl. 
kind of exercising parental authority following divorce or separation ${ }^{2}$ (Gajda, 2020). Joint physical custody is permitted by provisions of the Family and Guardianship Code $(1964)^{3}$, albeit not directly, but as part of a parenting agreement, sometimes referred to as a parenting plan, i.e. a voluntary, written agreement between parents on the method of exercising parental authority and maintaining contact with the child (Łukasiewicz, 2018, pp. 57-58). To begin with, it is worth mentioning that under Polish law, parental authority and the legal concept of contact are separate components. In general, both legal parents acquire parental authority unless it has been restricted, limited, suspended or deprived. In those cases as well as in the situation when both parents have full parental authority, but the child is residing permanently with one of them - contact guarantees that the relationship with the other continues. Pursuant to Article 113 of the Family and Guardianship Code, "regardless of parental authority the parents and the child have the right and duty to stay in contact with each other" (Zajączkowska, 2017, pp. 98-99). Such a solution affects the character and content of a parenting plan.

The Family Court may keep parental authority within both parents if they submitted, consistent with the welfare of the child, an agreement (Article $58 \S 1$ of the Family and Guardianship Code, 1964). In the absence of a parenting agreement, the Court determines the method of the joint exercise of parental authority, having regard to a child's right to both parents (Article $58 \S 1$ a of the Family and Guardianship Code, 1964). A parenting plan outlines how parents will continue to care and provide for their children after they separate. An effective plan is personalized to fit the needs of a family situation and details practical decisions about children's care in such areas as: living arrangements, travelling and relocation with a child, parenting style, parent communication, education, health care, child support and financial information, religion, emotional well-being, revising a plan, and exchanges. It aims to assist parents in resolving arrangements informally ${ }^{4}$ and amicably. A very important point in this plan is parenting time schedule because it shows when a child is with each parent. If the parents are granted joint physical custody, the child typically will move back and forth between their residences. It means that the child spends substantial time living with both parents, and both have equal responsibility to physically care for the child. It should be noted that joint physical custody does not mean that parents have equal time with the child. Rather, both parents have substantial and frequent time. An adopted model of the parenting plan refers to the US model for the parenting plan, which boils down to the negotiations between parents and making

2 This applies to parents who are married but who remain separated (legal or actual), as well as to parents who were never married.

3 Journal of Laws of 2019, item 2086.

4 A parenting plan is not automatically legally binding. 
a voluntary declaration before an authority to pursue a specific method of exercising parental authority and maintaining contact with the child.

The term joint physical custody, although not stated explicitly in the text of the Family and Guardianship Code (1964), appears in the text of the Act of the 11 February 2016 on state assistance in upbringing of the children ${ }^{5}$, but without a definition and any clarification. Furthermore, the provisions of the Code of Civil Procedure (1964) ${ }^{6}$ are relevant to "the judgement, in which the Court determined that the child will reside with each parent in recurring periods of time". ${ }^{7}$ It is also necessary to point that these provisions, introduced by the Act of 25 June 2015, are intended to apply joint physical custody, but the concept in question is not regulated by the Code of Civil Procedure (1964). This is a systematic defect in the legal system: the rules of procedure refer to a legal matter, and that does not come from the substantive provisions (Danilewicz-Prokorym, 2016, p. 378). This gives rise to considerable legal uncertainty and leads to a different treatment by the Polish courts and public authorities.

It is worth mentioning in this context that joint physical custody cannot be equated with "alternating parental authority" which is illegal under Polish law. In case of alternating parental authority, a child would spend some time, e.g. about half a year, with one of the parents, and during that period of time that parent would have the sole exercise of the parental authority. On the other hand, in the case of joint physical custody, it is not parental authority that is shared, but the time that a child lives with either of the parents, both of whom have full parental rights and responsibilities all the time. In the case-law of the national Supreme Court, prohibition of the alternating parental authority was formulated as early as the Supreme Court of Poland judgement of 22 April 1952.

\section{Joint physical custody: Theory and Practice}

One could ask what is the relationship between joint physical custody and parental authority. Both institutions are related to one another in a certain way, depending on detailed regulations in light of the specifics of its own legal system. In the Polish legal system, this relationship can be as that of encompassing. A decision on joint physical custody is a decision on parental authority, not the other way

5 Journal of Laws of 2019, item 2407. It is also popularly called the "Act 500+" because it introduced the right to untaxed child benefits of PLN 500 per month, which is granted to each second and subsequent child until they are 18 years of age. Since 1 July 2019, the "500+" Programme allows every child to receive the benefit until they reach legal age.

6 Journal of Laws of 2020, item 1017.

7 See Articles $5821 \S 4,59822$ and $7562 \S 1$ point 3 of the Code of Civil Procedure (1964). 
around. Awarding parental authority to both parents when they separate or divorce does not automatically mean established joint physical custody.

Joint physical custody basically is when the child has two residences, spending at least $35 \%$ of the time with each parent (Nielsen, 2015, p. 81). Polish law makes a distinction between the child's place of (usual) residence and child's domicile, with the establishment of the latter being an important element of parental authority. Pursuant to Article $26 \S 1$ of the Civil Code $(1964)^{8}$, the domicile of the child under parental authority is the domicile of the parents or of the one who has exclusive parental authority or to whom the exercise of parental authority is entrusted. Meanwhile, if both parents have equal parental authority and have separate domiciles, the child's domicile is with the parent with whom the child permanently resides. If the child does not permanently reside with either of the parents, the Family Court will decide on the child's place of residence. The domicile of the child should be distinguished from the actual place of residence, which is determined by the will of its parents (Domański, 2016, pp. 103-104).

Although the institution of joint physical custody has not been regulated expressis verbis in Polish family law, this method of the exercise of parental authority cannot be precluded. The prevailing view is that it ought to be possible to decide on the question of joint physical custody if both parents enjoy full parental authority. In practice, parents can create a specific joint physical schedule to find out who has their children when. Below are listed a few of the most common schedules:

1) $80 / 20$ custody schedule: when the children live with Parent A but live with Parent B 20\% of the time;

2) $75 / 25$ custody schedules: when the children live with Parent A for 5 days and live with Parent B for 2 days per week;

3) 70/30 custody schedules: when the children live with Parent A but live with Parent B for a week during every $3^{\text {rd }}$ week;

4) 60/40 custody schedules: when the children live with Parent A during the week and live with Parent B during the weekends;

5) 4/3 custody schedule: when the children live with Parent A for 4 days (weekends and some weekdays) and live with Parent B for 3 days (weekdays $)^{9}$;

6) 2-2-3 rotation: when the children live with Parent A for 2 days, then Parent B for 2 days, then Parent A for 3 days, once the week is over, the rotation flips;

7) 2-2-5-5 custody schedule: when the children live with Parent A for 2 days, then Parent B for 2 days, then Parent A for 5 days, then Parent B for 5 days as shown in the figure 1 ;

8 Journal of Laws of 2020, item 875.

9 This is similar to the $60 / 40$ custody schedules, but the $4 / 3$ schedule does not include weekends for Parent B. 
8) 3-3-4-4 custody schedule: when the children live with Parent A for 3 days, then Parent B for 3 days, then Parent A for 4 days, then Parent B for 4 days as shown in the figure 2;

9) alternating weekends custody schedule: when the children live with Parent A and with Parent B every other weekend;

10) alternating weeks custody schedule: when the children live with Parent A for 7 days, then Parent $B$ for 7 days ( 7 days on 7 days off);

11) alternating every 2 day: when the children live with Parent A for 2 days, then switching for two days ( 2 days on 2 days off). ${ }^{10}$

\section{Figure 1.}

2-2-5-5 custody schedule (two-week schedule) ${ }^{11}$

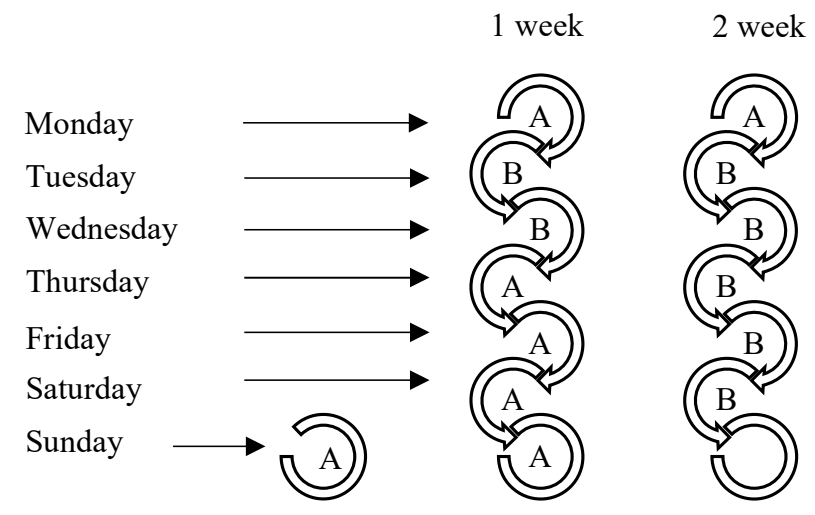

Note. Own elaboration.

10 CustodyxChange (n.d.). 50/50 Custody \& Visitation Schedules: 6 Examples. Retrieved July 14, 2020, from https://www.custodyxchange.com/examples/schedules/50-50/.

11 This is important: 2-2-5-5 schedule allows the children to be with one parent every Sunday and Monday, and other every Tuesday and Wednesday with Thursday, Friday and Saturday alternating. 
Figure 2.

3-3-4-4 custody schedule (two-week schedule) $)^{12}$

1 week $\quad 2$ week

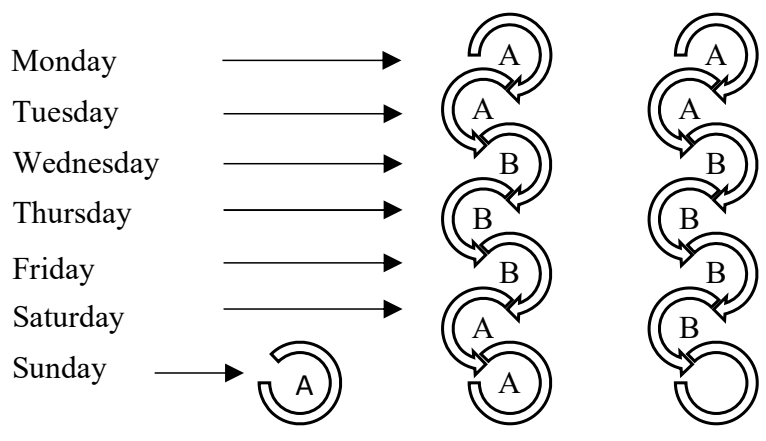

Note. Own elaboration.

In foreign legal systems, it has already become a rule today that both divorcing parents should continue to be deeply involved with their children and be given permission by the court and lawyers to do so. When courts give permission, society listens. This kind of leadership by courts, as an institution would help eliminate the message now given by courts which is that if you are divorced everyone expects you to become enemies. When any other relationship ends, society does not say: "Be enemies", rather it asks: "Why not try to be friends?". As E. O. Fisher and M. S. Fisher claim, it is essential for divorcing parents to maintain an amicable relationship not only for the sake of the children but also for their own sake so that they can get on with the task of having a full and rewarding life (Elkin, 1982).

Actually, until the 1970s it was typical for the courts to award parental authority over joint minor children to one of the parents following divorce or separation proceedings (sole custody). In the course of time, the view prevailed that children should maintain regular contact with both parents unless it is contrary to their interests. This was largely due to the fathers' rights movements, as is currently the case in Poland. In 1979, in California, as the first state, statutory solutions to award joint custody were enacted (Lemon, 1981, pp. 485-531). Until the second half of the 1990s all state legislatures permitted joint custody, except South Carolina. Currently, joint custody is allowed in all states, either by law (statutorily) or on the basis of the

12 This is important: 3-3-4-4 schedule allows the children to be with the same parent every Sunday Tuesday and with the other every Wednesday - Friday. 


\section{JOINT PHYSICAL CUSTODY AFTER PARENTAL SEPARATION...}

case law. It is now the prevailing practice regarding the regulation of the exercise of parental rights and obligations after divorce.

Following that thought process, there is a rule that after divorce, both parents keep parental responsibility for the children unless a court decides otherwise. Both parents keep the rights of guardianship over a child. The exception to this is when sole responsibility is given to one parent. This is reflective of the prevailing view held internationally, both in Europe and the USA, that this type of child custody (an agreement or order) is in a child's best interests. It is also the best safeguard the interests of divorcing parents - as a bond with their child is maintained. While awarding parental authority to both parents, also after their divorce, has not raised any doubts for some time now, the issue of admissibility of the establishment of joint physical custody by courts has only recently begun to be widely discussed and has already created a controversy in the public's mind.

Unlike many contemporary foreign legal orders, in the Polish legal system, awarding to both divorcing parents full parental rights is not a rule where exceptions are very rarely granted (Domański, 2016, p. 101). However, it is not the rule of law, but rather the practice of the Polish courts. On August 29, 2015, an amendment to the Family and Guardianship Code modified the rules concerning parental authority after divorce or separation. As a general rule, both parents remain responsible for raising and caring for the children. An exception to this general rule may occur if it is required for the child's welfare. In this respect it should however be noted that in view of the provisions of Article 58 of the Family and Guardianship Code (1964) in cases of divorce ${ }^{13}$ and Article $107 \S 1$ of the Family and Guardianship Code (1964) - in cases of separation for a different reason other than divorce, the adjudication on awarding parental authority to both parents requires meeting additional criteria. In other words, awarding full parental rights to one of the parents and at the same time limiting parental authority of the other is therefore seen as a rule. This should be viewed as an anachronism requiring changes of a statutory nature (Justyński, 2011, pp. 5-11).

When a marriage breaks up, a parent with custody of a child and who is responsible for the physical care of the child, including where the child lives and the daily decisions about how the child is raised, is nearly always the mother. It is connected with a stereotypical perception that a mother is better at raising a child than a father because traditionally it is considered normal for the mother to stay home with the children (Bieszczad, 2019, pp. 115-128). Courts are not supposed to factor in gender when making a child custody decision. The truth is that gender and genetics do not make a person a good parent, effort and experience does.

13 Article 58 of the Family and Guardianship Code (1964) applies also to legal separation (Article $\left.61^{3} \S 1\right)$. 
According to Statistics Poland, in 2018 there was a total of 36214 court decisions on care for minor children, as a consequence of a divorce. Decision on children care granted:

1) only to mother - in 13333 cases;

2) only to father - in 1276 cases;

3) both of them - in 20955 cases;

4) separately to mother and father - in 262 cases (GUS, 2019, p. 246).

On the basis of the data provided above, the stereotype of the good mother and the stereotype of the bad father after divorce, especially in the mind of judges deciding on parental authority, has begun to fade. However, it should be remembered that gender discrimination is not just about who will be awarded custody. It often happens that a father who was granted contact cannot actually exercise his rights in this regard as the mother makes it difficult or even impossible for him to do so. Among the judgements where the exercise of parental authority was awarded to both parents, there is an increasing number of those, where joint physical custody is adjudicated. Polish judges indicate that it is increasingly common for request to be made in courtrooms for joint physical custody and add that this is a result of a growing level awareness of Poles, following e.g. from the fact that, for over 16 years now, Poland has been a member of the EU, and the realization of the principle of free movement. This enabled Poles to see and experience interpersonal relations in various Member States. Furthermore, judges point to more active involvement of fathers in raising their both preschool-age and school-age children. This stands in contradiction with a model that prevailed some 20 years ago where the mother was running the household and raising of children, and the father's role was to provide for the family. Needless to say that this change was possible mainly because of the economic and social changes taking place, including changes in the structure of gainful employment among men and women. One should not forget the improving living standards and the growing income of the Polish family.

\section{The debate on shared parenting in Germany and Sweden}

As a comparison, in German family law, it is a rule that after divorce, both parents continue to exercise parental authority over their children. Joint custody, or more strictly joint legal custody which means that both parents have the legal authority to make major decisions for the child ${ }^{14}$, does not expire after divorce. In line with the provisions of the Bürgerliches Gesetzbuch (1900) ${ }^{15}$, when parents

14 These include decisions regarding education, religion, and health care.

15 The Bürgerliches Gesetzbuch is the civil code of Germany. It went into effective on January 1, 1900. 
live separately and have joint custody, each parent may apply for the Family Court to transfer parental custody or part of parental custody to him or her alone. This application is to be granted without the other parent's consent or is to be expected that the modification or termination of the custody order is particularly conducive to a child's best interests (section 1671). Section 1687 of the Bürgerliches Gesetzbuch (1896) is noteworthy. It states that parents who live separately and have joint custody, jointly decide on important matters concerning the child. Furthermore, the parent with whom the child lives may, upon the consent of the other parent or pursuant to a court decision, independently decide on all day-to-day matters of the child's life.

The German legal system adopted a model for adjudicating matters regarding parental authority in which the court leaves both parent's authority intact and at the same time determines the child's habitual residence. The aforementioned section 1687 of the Bürgerliches Gesetzbuch (1896) specifies the rights of the parent with whom the child will reside. This is the opposite situation than in the Family and Guardianship Code (1964). Before the amendment to this Code in 2015, the Polish legislator's intention was to limit the rights of the parent who will not be involved in the daily physical care of the child, and not to determine the rights of the parent who will provide it. In the case of divorce, the German legislation gives preference to joint custody. Although this institution is similar to joint physical custody, the latter has not been regulated in the Bürgerliches Gesetzbuch (1896). Joint custody was passed in 1997. It should be noted that in 1998 automatic granting parental authority to either parent and restricting the other parent's authority to specific obligations and rights with regard to the child in a divorce, was deemed to be unconstitutional by the Bundesverfassungsgericht [Federal Constitutional Court]. ${ }^{16}$ Moreover, in its decision of 19 November 2004, the Federal Constitutional Court specified the conditions which must be satisfied to deprive a parent of parental authority. ${ }^{17}$ And since that time, the aim is to strive to ensure that both parents retain full parental rights and responsibilities with respect to their child.

The country with the largest proportions of joint physical custody is Sweden. Research carried out in 2009 revealed that in $28 \%$ of cases courts awarded joint physical custody to both parents, with equal parenting time for either parent. For comparison, in 1989 the corresponding proportion was merely $1 \%$ of all cases. It is worth stressing that Swedish courts have been able to decide on joint physical custody since 1977. Meanwhile, since 1992 it has been presumed that in the event of a family break-up, parental authority shall be exercised jointly and equally. Sweden pursues an active policy for parental authority. What is more, Sweden was

16 The Federal Constitutional Court is the supreme constitutional court for the Federal Republic of Germany.

17 Judgement of the Federal Constitutional Court for the Federal Republic of Germany (German: Bundesverfassungsgericht) of 19.11.2014, application no. BvR 1178/14. 
the first country to allow mothers and fathers to use paid parental leave (Bergström et al., 2015, pp. 769-774). One of the reasons for this is a liberal culture of the Swedes, who largely accept non-traditional family forms. Another important fact is that Sweden has long had some of the highest proportions of citizens with higher education degrees (Kubalski et al., 2019) Data from Eurostat suggest that in 2000 $31.8 \%$ of Swedes had completed tertiary education, and in 2016 - as many as $51 \%$. This proportions are lower than in Poland. It was $12.5 \%$ in the year 2000, with the figure rising to $44.6 \%$ in 2016. (European Commission, 2017).

\section{Joint physical custody and children's well-being}

In recent years, the issue of joint physical custody has been analysed in depth in Polish literature on family legal matters. W. Stojanowska carried out an extensive criticism of joint physical custody and presented a number of different arguments to support her claims. As a result, she precluded the admissibility of joint physical custody. According to W. Stojanowska, the best interests of the child always (emphasis mine - K.K.) stands in the way to award joint physical custody (Stojanowska, 2019, pp. 117-130). It is hard to agree with the view presented by W. Stojanowska. Analysis of legal regulations of the Family and Guardianship Code (1964) concerning relationships between parents and children (Articles 87-1136), and the arguments raised by the author, led to the following conclusions. First of all, the provisions of the Family and Guardianship Code (1964) do not preclude de lege lata joint physical custody. Secondly, whenever the Family Court rules on parental responsibility, it must be guided by a child's best interests. So if a child's best interests means that joint physical custody should not be adjudicated, the Family Court will rule accordingly. Furthermore, a child's welfare shall be a primary consideration and the analysis in this case is based on an analysis in concreto and not on hypotheses. Which is to say, an account shall be taken of the whole context and of individual circumstances. In the light of the particular circumstances of the case, joint physical custody may in fact be the best solution for a particular child in his or her specific circumstances, namely his or her age, bond with both parents, living in the vicinity, parents' jobs requiring frequent travel, etc. For this reason, this overgeneralisation cannot be viewed as correct and substantive.

Incidentally, is should also be pointed out that the Polish legislator does not uses the term "best interests of the child", instead using the "welfare of the child". According to Article $93 \S 3$ of the Family and Guardianship Code (1964), the 
essence of parental authority ${ }^{18}$ should be the welfare of the child the public interest. ${ }^{19}$ The concept exists in the legal language, however, it is understood in two ways: as a language of legal texts (law-making instruments), and a language of legal practice and legal science. It is also used in normal speech. However, its statutory definition has yet to be elaborated. One could argue that without a clear definition, the introduction of this concept could lead to a wide variation of interpretations which could undermine the effectiveness of the due diligence system. In this respect it is noted that the Convention on the Rights of the Child (1989) ${ }^{20}$, which became a point of reference for internal policies and detailed solutions in international law. The Convention on the Rights of the Child (1989) uses the term "best interests of the child". While the Convention on the Rights of the Child (1989) does not define the term, "best interests of the child", most of its provisions refer to the primary of the "interests of the child", and its scope is set out in Article 3 (2). The notion of the child's best interests or welfare is the axis of all deliberations concerning the situation of children whose parents got divorced also in the American law. ${ }^{21}$ The majority of the representatives of doctrine agree that it is pointless to attempt the definition of the child's best interests or welfare. They would rather advise focusing on the measures that the court shall take into consideration when it autonomously adjudicates on the specific case.

Some studies indicate that upon mutual consent of both parents, joint physical custody has a positive impact on child development (Andrzejewski, 2019, p. 23). On the other hand, if parents do not communicate respectfully with each other and do not have a good strategy for resolving conflicts, the result is chronic, unresolved conflict between parents. There is an ongoing hostile emotional tone between parents that continues to erupt over time and in the same patterns. Conflict between parents

18 However, the term "parental authority" has not been defined. For the purpose of this paper, "parental authority" means a set of obligations and rights of parents with regard to a child for the purpose of the proper care of the child and their assets.

19 The public interest should generally be consistent with the welfare of the child. After all, it is the business and duty of society to provide the child of nature with a fair and peaceful opportunity to pursue self-maintenance, with parents caring for child development and thus raising them to independence and preparing them properly to work for the benefit of society and the public.

20 The Convention on the Rights of the Child, signed 20 November 1989, is a human rights treaty which sets out the civil, political, economic, social, health and cultural rights of children. Poland signed and ratified the Convention on the Rights of the Child. It has been in force since 7 July 1991. Poland was also among initiators of the Convention on the Rights of the Child. In 1978 Poland proposed the idea of a UN Convention on the Rights of the Child that would be legally binding for all nations.

21 It should be stressed at this point that each state has its own unique legislation governing family law. However, state family law is frequently strongly affected by the model law known as the Uniform Marriage and Divorce Act (1970 amended 1971 and 1973), and the solutions adopted in the respective states are quite similar. This is why, although the term "American law" is simplification, it should not be viewed as incorrect. 
is harmful to children. According to A. I. Schepard, joint custody is associated with lower levels of conflict between parents (Schepard, 2004, p. 35). ${ }^{22}$ Besides, some studies draw attention to problem behaviour and psychological problems of children in joint physical custody. In an influential book entitled Beyond the Best Interests of the Child $(1973)^{23}$, J. Goldstein, A. Freud and A. J. Solnit argue that splitting the child's place of residence between two homes will threaten the child's relationship with both parents (Goldstein et al., 1973, p. 38). They claim that children lack the capability for maintaining positive emotional ties with individuals who are hostile to each other, and they argue that children who are asked to maintain these ties will suffer from serious loyalty conflicts (Berg-Cross, 2000, p. 90). Moreover, they put forward the idea of a "psychological parent", which means a person who has a parental relation with a child, whether or not the two are biologically related. The most controversial aspect of Goldstein, Freud, and Solnit's book was the recommendation that in a typical divorce, the court should determine whether the mother or the father is the psychological parent and give that person sole custody of the child (Goldstein et al., 1973, p. 23-25). ${ }^{24}$

As noted P. M. Stahl, more times than not, when parents separate it is the schoolage children that develop loyalty conflicts between their parents. A child of this age wants to please both parents and does not yet understand his or her needs vis-à-vis his or her relationships with both parents. In trying to please, the child will often feel conflicts in which pleasing his or her father will automatically lead to feelings of rejection from his or her father and vice versa (Stahl, 1994, p. 39). It may also happen that joint physical custody tends to induce a feeling in child he or she does not belong to either family (Huston v. Huston, 1963). The Iowa Supreme Court noted that decades ago, Iowa appellate courts have disfavored joint physical custody in dissolution cases as not in the best interest of children, and outlined reasons against joint physical care arrangements (Burham v. Burham, 1979). Specifically, the court pointed out that joint physical custody is destructive of discipline and in some instances can permit one parent to sow seeds of discontent concerning the other, which can result in a spirit of dissatisfaction in the children and their rebellion against authority.

However, under some circumstances a joint physical custody arrangement would not serve the child's welfare (well-being). For instance, a judge probably will

22 By the term "joint custody", the author understands here both joint legal custody (parents substantially share decision-making for their child) and joint physical custody (the child spends substantially equal time at each parent's residence).

23 The book was a collaboration among a law professor (Goldstein), a child analyst (Freud), and a child psychiatrist (Solnit).

24 They recommended that the chosen parent (custodian) to be given full decision-making authority over the child, including regulating or even putting an end to visits between the child and the noncustodial parent. 
not award joint physical custody to parents who relocate hundreds of miles apart and who cannot get along. Also, a judge is unlikely to give joint physical custody in the case of parent with a history of domestic violence. What is more, one of the major disadvantages of such custody arrangement is how stressful it is for children to persistently go back and forth between homes. Some kids have a hard time adjusting to move from one parent's house to the other. It can be particularly hard on small children who prefer stability (Otterstrom, n.d.).

Notwithstanding this, the possibility to award both parents joint physical custody is perceived by courts as the most convenient way out of exceptionally difficult judicial situation. It allows the judge to avoid the dilemma of choosing between parents. It is often unnecessary to choose one parent over the other, who, in the opinion of the court, is better fitted to physical care for the child. Therefore, joint physical custody eliminates the need to put one of the parents in a bad light, hurt his or her parental feelings and stigmatise that parent (Kosińska-Wiercińska, 2011, pp. 12-32). What follows is that there no winner/loser dichotomy. M. Elkin ${ }^{25}$ believes that , "Joint custody tends to equalize the power and authority between the parents. Unequal power and authority in any relationship engenders ongoing frustration and hostility. Unequal power in divorce creates a $>$ winner/loser $<<$ relationship which is a barrier to personal and familial growth and development" (Elkin, 1991, pp. 1115). Furthermore, none of the parents becomes a guest or a "visitor", a term which now carries negative connotations. As pointed out by M. Andrzejewski in Polish reality the alternation of custody shall be understood as parents' equal access to the child (Andrzejewski, 2018, p. 87).

In a lot of foreign jurisdictions the joint parental authority is a privileged solution being applied first among the different solutions of custody in case of breakup of marriage, and there is a tendency of joint physical custody as well. This confirmed by research conducted by L. Nielsen, which says that children in joint physical custody had better outcomes than children in sole physical custody. The measures of well-being included: emotional health, academic achievement, behavioural problems, physical health and stress-related illnesses and relationships with parents, stepparents, step-siblings, and grandparents. And interestingly, infants and toddlers in joint physical custody have no worse outcomes than those in sole physical custody (Nielsen, 2017).

25 M. Elkin is the senior statesman of the conciliation courts' movement and founding editor of the Conciliation Courts Review. In his publications he often uses terms such as "Parents are Forever" and "Close the Book Gently". The first is addressed to children of separated parents, and states that separation does not have negatively impact on the parent-child relation. The second concept is aimed at parents and argues for staying classy after a breakup. 


\section{Impact of COVID-19 on joint physical custody}

On December 31, 2019, Chinese authorities alerted the World Health Organization (WHO) of pneumonia cases in Wuhan (Hubei Province, China), with an unknown cause. ${ }^{26}$ What started as a mystery disease was first referred to as 2019-nCoV and then named COVID-19. ${ }^{27}$ COVID-19 has affected every country in the world, and no community has been adequately prepared to deal with the pandemic. The illness has killed more than 555,000 people and infected over 12 million, according to data compiled by Johns Hopkins University (n.d.). As well as serious implications for people's health, COVID-19 is significantly impacting the economy, businesses, industries, governments and society. COVID-19 has caused many sporting and cultural events around the world to be cancelled or postponed. ${ }^{28}$ Conferences are on hold or exclusively online. For instance, the International Conference on Shared Parenting, which is organised regularly since 2014 by the International Council on Shared Parenting ${ }^{29}$, has been reformatted as a livestreamed online conference. ${ }^{30}$

Physicians, health professionals and researchers are calling on people to stay at home if possible, to avoid crowds and to self-quarantine if you have come in contact with someone who is positive for the virus or who just "might" be infected. COVID-19 has impacted everyone, some even more so than others. In such circumstances, the question arises what might be the implications of this virus for those embroiled with family law issues such as joint physical custody. Many parents must make substantial changes to the daily patterns, arrangements, and rhythms of their individual and family lives. For many families, COVID-19 can mean making

26 Initially, authorities in Wuhan reported that the first cases of the virus emerged at a wet market in Wuhan, called the local Huanan Seafood Wholesale Market - offering live wild animals for sale. In May 2020, however, Chinese scientists dismissed it.

27 COVID-19 is the most recently discovered coronavirus disease caused by coronavirus. But more generally, coronaviruses are a large family of viruses which may cause illness in animals or humans. In humans, several coronaviruses are known to cause respiratory infections ranging from the common cold to more severe diseases such as Middle East Respiratory Syndrome (MERS) and Severe Acute Respiratory Syndrome (SARS). Further information available at https://www. who.int/emergencies/diseases/novel-coronavirus-2019 (accessed on July 10, 2020).

28 Among the most prominent events to be affected was the Tokyo 2020 Olympic and Paralympic Games which has been postponed to 2021 .

29 The International Council on Shared Parenting is an international non-profit organization that promotes scientific research and makes recommendations on the rights of children whose parents do not live together. It was set up in 2013 by a group of international shared parenting experts. "Shared parenting" means more than enough equivalent, alternating care of children whose parents are living apart. More information available at https://www.twohomes.org (accessed on July 10, 2020).

30 Nevertheless, the theme of the conference will remain the same: "The intersection of shared parenting and family violence". 
big changes in everyday routines with regard to financial hardships. For others, it can mean raised tension in parenting relationships, anxiety in children or general fear (UC Health, 2020). Parenting is challenging enough when both parents live in the same home. When they do not live together, as after a divorce or separation, things can get even harder. It is crucial that divorced or separated parents carefully consider the wider ramifications of having a child go back and forth between homes. Until the coronavirus is over, physical distancing to slow the spread of the pandemic can require parents to change the way they share their children's time as they normally would. Divorced or separated parents should talk calmly to each other and come up with a plan that works best for them, and the children the current parenting schedule may prove to be temporarily unfeasible. There is no doubt, though, that COVID-19 can add to the stress of co-parenting. Whenever possible, parents should work together to make sure their children can have safe, regular, positive and predictable contact with both parents while social distancing.

If the child exhibits any of the well-publicised symptoms, this is a high temperature, a new, continuous cough and a loss or change to sense of smell or taste, then that child should stay at home (self-isolate) where the symptoms first appear and do not leave this household or have visitors. The next step will be to get a test to check if the child has coronavirus as soon as possible. It is worth noting that if the child is infected, then he or she may pass the virus along to half siblings and other family members in the other home. However, experts are still learning about COVID-19. There are far fewer cases of the disease reported in children. COVID-19 seems to usually cause a milder infection in children than in adults (Ravin \& BenJoseph, 2020). If health factors dictate that the child should not be changing homes, the following issues might be considered by parents:

1) the nature of work - perhaps one parent has a job requiring more contact with the public and therefore more risk for household members;

2) living conditions - perhaps one parent has more the space in and around the house where the child can play while keeping the recommended physical distance;

3) learning conditions - perhaps in one house the child has his or her own room where he or she has a computer console in this room with Internet access;

4) age and health of household members - perhaps there is someone in a highrisk group, this is over the age of 60 , suffering from underlying medical conditions, or immunocompromised (Hill \& Blackstone, 2020).

Not all parents can figure this out for themselves, especially in high conflict situations. As pointed out by G. Colman from Gene C. Colman Family Law Centre, it would likely be a good idea for the parents with whom the child currently resides to first seek advice from a qualified public official or from the child's physician. Parents cannot abuse COVID-19 to deny the child all contact with the other parent. 
The alternative modes of contact and streaming applications such as Skype cannot be overlooked (Colman, 2020).

With joint physical custody, parents need to communicate on a very regular basis in order to keep each other informed of how their child is doing, day in and day out. For joint physical custody to work, communication is key. It requires maximum ongoing and mature communication and cooperation between divorced or separated parents even during the years following their divorce or separation (Coates, 2014, p. 115). The parents may communicate with each other in different ways: personally, mobile telephone, mobile texting, email, work telephone, letter, or other. In the time of coronavirus, experts advise divorced parents as well as parents who are going through a divorce stay in touch through writing. Sharing clear plans will likely reduce conflict and keep households safe from infection (Moore, 2020). It probably will not work for parents who cannot solve financial or scheduling issues. The Chief Justice of the Family Court and Federal Circuit Court of Australia, W. Alstergren, explained that if parents cannot reach agreement on new arrangements, they should generally communicate with each other about their ability to comply with current orders, and they should attempt to find a practical solution to these difficulties. In other words, they should follow their court orders unless their child's safety is compromised. If one parent is seeking to deviate from family court orders due to health concerns W. Alstergren said such requests: “(...) should be considered sensibly and reasonably. Each parent should always consider the safety and best interests of the child, but also appreciate the concerns of the other parent when attempting to reach new or revised arrangements. This includes understanding that family members are important to children and the risk of infection to vulnerable members of the child's family and household should also be considered" (Family Court of Australia, 2020).

Not all parents agree on what to do during a quarantine. There are disagreements about the severity of COVID-19. While one parent may be more lenient about letting their child do what the child normally does, the other may want to limit the exposure. Having a physician to give the quarantine order could help solve this problem (Schoolman, n.d.). During this time uncertainty, it is very important for parents to be as flexible as possible because parenting plan may not necessarily correspond to local coronavirus orders issued by government officials. Finding a temporary yet mutually beneficial solution will help parents find a way to spend time with their children in a healthier way.

\section{Conclusions}

There is no universal method that works for all problems related to the parentchild relationship and parental authority, including custody and visiting rights 
following divorce or separation. There is no universal method for solving such problems in a way that would be best for the child. Each case is different. Joint physical custody has been studied for more than a quarter-century, with the majority of studies indicating the significance for children. The critical factor appears to be conflict between parents. When parents cooperate and minimize conflict, children do better with joint physical custody. If there is a significant conflict between parents, according to research, joint physical custody provides no benefits and children do no better nor worse than they do in sole custody (Paulbeck, 2020).

This solution requires cooperation between parents and means that there is a wide range of tasks and activities that will require ongoing contacts. It may also be the case that the court's decision to use joint physical custody will open new fields of conflict if the parents focus on the dispute and not on the child. Moreover, both parents are obliged to harmonise their parenting styles and prepare common rules as to many basic issues like doing homework, some household chores, bedtime, leisure activities or how many of each candy the child could be allowed per day.

The coronavirus pandemic has brought with it new challenges for families across the globe. Usual routines have had to change. For parents who live apart from each other this might mean a change to usual arrangements for joint physical custody of their children. In normal circumstances joint physical custody requires broad cooperation and now in times of crisis, we need over-communication about children and plans. Only a very tight and coordinated co-parenting plan can make the whole family safer.

\section{Acknowledgements}

This work was supported by grant 2019/33/N/HS5/00284, funded by the National Science Centre, Poland.

\section{REFERENCES}

Act of 25 February 1964 - Family and Guardianship Code. Journal of Laws of 2019, item 2086.

Act of 23 April 1964 - Civil Code. Journal of Laws of 2020, item 875.

Act of 17 November 1964 - Code of Civil Procedure. Journal of Laws of 2020, item 1017.

Act of the 11 February of 2016 on state assistance in upbringing of the children. Journal of Laws of 2019, item 2407.

European Commission (2017). European Semester Thematic Factsheet. Tertiary Education Attainment. Retrieved July 7, 2020, from https://ec.europa.eu/info/sites/info/files/file_import/ european-semester_thematic-factsheet_tertiary-education-attainment_en.pdf.

Andrzejewski, M. (2018). Piecza naprzemienna - między formalną dopuszczalnością a merytoryczną zasadnością jej orzekania [Joint physical custody - between formal admissibility and substantive validity of its adjudication]. In. A. Czerederecka (Ed.), Rodzina w sytuacji okołorozwodowej. 


\section{EASTERN EUROPEAN JOURNAL OF TRANSNATIONAL RELATIONS}

Wspótczesne dylematy psychologiczne i prawne (pp. 85-118). Kraków: Instytut Ekspertyz Sądowych.

Andrzejewski, M. (2019). Wokół Projektu Kodeksu Rodzinnego przedłożonego w lipcu 2018 r. przez Rzecznika Praw Dziecka [On the Family Code Bill Submitted by the Ombudsman for Children in July 2018]. Prawo w działaniu. Sprawy cywilne, 40, 9-42. Retrieved from https://pwd.iws. gov.pl/wp-content/uploads/2020/02/Marek-Andrzejewski.pdf.

Berg-Cross, L. (2000). Basic Concepts in Family Therapy. An Introductory Text. New York, London,Oxford: Routledge. https://doi.org/10.4324/9781315809533.

Bergström, M., Fransson, E., Modin, B., Berlin, M., Gustafsson, P.A., \& Hjern, A. (2015). Fifty moves a year: is there an association between joint physical custody and psychosomatic problems in children? Journal of Epidemiology \& Community Health, 69, 769-774. http://dx.doi. org/10.1136/jech-2014-205058.

Bieszczad, M. (2019). Piecza naprzemienna w przypadku braku pisemnego porozumienia o sposobie wykonywania władzy rodzicielskiej i utrzymywaniu kontaktu [Joint physical custody in the absence of a written agreement between parents on the method of exercising parental authority and maintaining contact with the child]. In D. Jaroszewska-Choraś, A. Kilińska-Pękacz \& A. Wedeł-Domaradzka (Eds.), Prawa dziecka. Perspektywa prywatnoprawna i społeczna (pp. 115-128). Gdańsk: Wydawnictwo Naukowe Katedra.

Bürgerliches Gesetzbuch (1986). BGB1. I S. 42, 2909; 2003 I S. 738; BGB1. I S. 607.

Coates, B.A. (2004). Divorce with Decency. The Complete How-To Handbook and Survivor's Guide to the Legal, Emotional, Economic, and Social Issues. Honolulu: University of Hawaii Press.

Colman, G. (2020). Covid-19 and how to navigate parenting schedules in the crisis. Gene C. Colman Family Law Centre. Retrieved July 13, 2020, from https://www.complexfamilylaw.com/ blog/2020/03/covid-19-and-how-to-navigate-parenting-schedules-in-the-crisis.shtml.

Johns Hopkins University (n.d.). COVID-19 Dashboard by the Center for Systems Science and Engineering (CSSE) at Johns Hopkins University (JHU). Retrieved July 10, 2020, from https:// coronavirus.jhu.edu/map.html.

CustodyxChange (n.d.). 50/50 Custody \& Visitation Schedules: 6 Examples. Retrieved July 14, 2020, from https://www.custodyxchange.com/examples/schedules/50-50/.

Danilewicz-Prokorym, W. (2016). Władza rodzicielska a kontakty z małoletnim dzieckiem. Instytucja pieczy naprzemiennej na mocy ustawy z dnia 25 czerwca 2015 r. o zmianie ustawy - Kodeks rodzinny i opiekuńczy oraz ustawy - Kodeks postępowania cywilnego (Dz. U. 2015, poz. 1062) [Parental authority and contacts with the child. Alternate care institution under the Act of 25 June 2015. "On Amendments to the Acts - Family and Guardianship Code and Code of Civil Procedure" (O.J. 2015, item 1062)]. Miscellanea Historico-Iuridica, 15(1), 371-380. https:// doi.org/10.15290/mhi.2016.15.01.22.

Domański, M. (2016). Orzekanie o pieczy naprzemiennej w wyrokach rozwodowych [Adjudicating alternating custody in judgments of divorce]. Prawo w dziataniu. Sprawy cywilne, 25, 97-148. Retrieved from https://iws.gov.pl/wp-content/uploads/2018/09/Maciej-Doma\%C5\%84skiOrzekanie-o-pieczy-naprzemiennej-w-wyrokach-rozwodowych.pdf.

Elkin, M. (1991). Joint Custody: In the Best Interest of the Family. In J. Folberg (Ed.), Joint Custody \& Shared Parenting (2nd ed., pp. 11-15). New York: Guilford Press. 


\section{JOINT PHYSICAL CUSTODY AFTER PARENTAL SEPARATION...}

Elkin, M. (1982). The Missing Links in Divorce Law: A Redefinition of Process and Practice. Journal of Divorce, 6(1-2), 37-63. https://psycnet.apa.org/doi/10.1300/J279v06n01_03.

Family Court of Australia (2020, March 26). Media Release - Statement from the Hon Will Alstergren - Parenting Orders and COVID-19. Retrieved from http://www.familycourt.gov.au/wps/wcm/ connect/fcoaweb/about/news/mr260320.

Gajda, J. (2020). Komentarz do art. 58 [Commentary for Article 58 of the Family and Guardianship Code]. In J. Gajda \& K. Pietrzykowski (Eds.), Kodeks rodzinny i opiekuńczy. Komentarz. Warszawa: C.H.Beck.

Goldstein, J., Freud, A. \& Solnit, A.J. (1973). Beyond the Best Interests of the Child. New York: The Free Press (MacMillan Publishing Co.).

Hill, D., \& Blackstone, J. (2020, May 6). Co-Parenting Through COVID-19: Putting Your Children First. American Academy of Pediatrics. Retrieved from https://www.healthychildren.org/ English/health-issues/conditions/COVID-19/Pages/Co-Parenting-Through-COVID-19.aspx.

Judgement of the Federal Constitutional Court for the Federal Republic of Germany (2014, November 19). Application no. BvR 1178/14.

Huston v. Huston - Judgement of the Supreme Court of Iowa (1963, July 16). Application no. 122 N.W.2d 892 .

Burham v. Burham - Judgement of the Supreme Court of Iowa (1979, September 19). Application no. 283 N.W.2d 269.

Judgement of the Supreme Court of Poland (1952, April 22). Application no. C414/52. OSN 1953, item 47.

Justyński, T. (2011). W sprawie tzw. opieki naprzemiennej [In the case of so-called joint physical custody]. Rodzina i Prawo, 19, 5-11. Retrieved from http://sedziowierodzinni.pl/wp-content/ uploads/2014/04/rodzina-i-prawo-nr-19.pdf.

Kosińska-Wiercińska, J. (2011). Władza rodzicielska nad małoletnim dzieckiem w razie rozwodu rodziców na tle prawa amerykańskiego [Parental authority over a minor in case of divorce in the context of American law]. Rodzina i Prawo, 19, 12-32. Retrieved from http:// sedziowierodzinni.pl/wp-content/uploads/2014/04/rodzina-i-prawo-nr-19.pdf.

Kubalski, M., Gołembiewski, T., \& Gee-Milan, E. (2019, March 2). Opieka naprzemienna - po zmianach $\mathrm{w}$ prawie szansa na dobra praktyka [Joint physical custody after amendments a chance for a good practice]. Prawo.pl. Retrieved from https://www.prawo.pl/prawo/opiekanaprzemienna-beda-zmiany-w-kodeksie-rodzinnym,378441.html.

Lemon, N.K. (1981). Joint Custody as a Statutory Presumption: California's New Civil Code Sections 4600 and 4600.5. Golden Gate University Law Review, 11(2), 485-531. Retrieved from https:// digitalcommons.law.ggu.edu/ggulrev/vol11/iss $2 / 2$.

Łukasiewicz, J.M. (2018). Problemy praktyczne związane z instytucją pieczy naprzemiennej [Practical problems Related to the Institution of Alternate Custody]. Forum prawnicze, 46(2), 53-64. Retrieved from https://forumprawnicze.eu/attachments/article/264/Lukasiewicz.pdf.

Moore, C. (2020, May 28). Coronavirus - related legal tips on handling shared custody. Lawyer shares advice for parents navigating custody battles during COVID-19. Fox Business. Retrieved from https://www.foxbusiness.com/lifestyle/coronavirus-divorce-custody-tips. 


\section{EASTERN EUROPEAN JOURNAL OF TRANSNATIONAL RELATIONS}

Nielsen, L. (2015). Shared Physical Custody: Does It Benefit Most Children? Journal of the American Academy of Matrimonial Lawyers, 28(1), 79-138. Retrieved from https://cdn.ymaws.com/ aaml.org/resource/collection/A75EB282-9216-437D-B4F8-132456499FD5/MAT111_1.pdf

Nielsen, L. (2017, June 20). '10 Surprising Findings on Shared Parenting After Divorce or Separation'. Institute for Family Studies. Retrieved from https://ifstudies.org/ blog/10-surprising-findings-on-shared-parenting-after-divorce-or-separation.

Otterstrom, K. (n.d.). Joint Child Custody: Do the Advantages Outweigh the Disadvantages? DivorceNet. Retrieved December 5, 2020, from https://www.divorcenet.com/resources/ divorce-and-children/joint-child-custody-advantages-disadvantages.htm.

Paulbeck, R.D. (2020). Research on Shared Parenting and Joint Custody. Robert D. Paulbeck, Attorney al Law. Retrieved July 10, 2020, from https://childrightsngo.com/newdownload/ downloadsection $8 /$ Research $\% 20$ on $\% 20$ Shared $\% 20$ Parenting $\% 20$ and $\% 20$ Joint $\% 20$ Custody\%20_\%20Robert\%20D.pdf.

Ravin, K.A. \& Ben-Joseph, E.P. (2020). Coronavirus (COVID-19). Retrieved July 13, 2020, from https://kidshealth.org/en/parents/coronavirus.html.

Schepard, A.I. (2004). Children, Courts, and Custody. Interdisciplinary Models for Divorcing Families. New York: Cambridge University Press.

Schoolman, A. (n.d.). Co-parenting hits separated families hard during coronavirus: 'It feels like we're missing huge life events'. USA Today. Retrieved July 13, 2020, from https://eu.usatoday. com/story/news/2020/06/13/coparenting-during-coronavirus-sharing-custody-harder-thanever/3004755001/.

Stahl, P.M. (1994). Conducting Child Custody Evaluations. A Comprehensive Guide. Thousand OaksLondon-New Delhi: Sage Publications, Inc. Retrieved from https://uk.sagepub.com/en-gb/eur/ conducting-child-custody-evaluations/book4641\#preview.

GUS (2019). Statistical Yearbook of the Republic of Poland, table 50 (74) Divorces by Court Decision on Care for Minor Children in 2018. Retrieved from https://www.google.com/url?sa=t\&rct=j $\& q=\&$ esrc $=$ s $\&$ source $=$ web $\& c d=\&$ ved $=2$ ahUKEwi $2 \mathrm{v}-216 \mathrm{YL} 1 \% 2 \mathrm{Fdownload} \% 2 \mathrm{Fgfx} \% 2 \mathrm{Fport}$ alinformacyjny $\% 2$ Fen $\% 2$ Fdefaultaktualnosci\%2F3328\%2F3\%2F13\%2F1\%2Fdemographic_ yearbook_of_poland_2019.pdf\&usg=AOvVaw2SdhhDBj0WMdkTnzIHFMCF.

Stojanowska, W. (2019). Prawo dziecka do wychowywania się w środowisku rodzinnym przewidziane w Konwencji o prawach dziecka (artykuł recenzyjny) [A child's right to grow up in a family environment provided for in the Convention on the Rights of the Child (a review)]. Państwo i Prawo, 875(1), 117-130. Retrieved from https://sip.lex.pl/komentarze-i-publikacje/artykuly/ prawo-dziecka-do-wychowywania-sie-w-srodowisku-rodzinnym-151346628.

UC Health (2020, April 4). Effects of COVID-19 on Families. Retrieved from https://www.uchealth. $\mathrm{com} / \mathrm{en} / \mathrm{media}-\mathrm{room} /$ covid-19/effects-of-covid-19-on-families.

Zajączkowska, J. (2017). Legal aspects of parent - child contact problems in Poland. Prawo w działaniu, 32, 98-112. Retrieved from https://iws.gov.pl/wp-content/uploads/2018/09/PwD_32_2017_J.Zaj\%C4\%85czkowska.pdf. 